medRxiv preprint doi: https://doi.org/10.1101/2021.07.27.21261116; this version posted July 28,2021 . The copyright holder for this preprint

(which was not certified by peer review) is the author/funder, who has granted medRxiv a license to display the preprint in perpetuity.

All rights reserved. No reuse allowed without permission.

\title{
Tolerability, safety and immunogenicity of intradermal delivery of a fractional dose mRNA -1273 SARS-CoV-2 vaccine in healthy adults as a dose sparing strategy
}

Geert V.T. Roozen, M.D. ${ }^{1,2}$, Margaretha L.M. Prins, M.D. ${ }^{2}$, Rob van Binnendijk, Ph.D. ${ }^{3}$, Gerco den Hartog, Ph.D. ${ }^{3}$, Vincent P. Kuiper, M.D. ${ }^{1}$, Corine Prins, BSc ${ }^{2}$, Jacqueline J. Janse, $\mathrm{MSc}^{1}$, Annelieke C. Kruithof, MSc ${ }^{2,4}$, Mariet C.W. Feltkamp, M.D. ${ }^{5}$, Ph.D., Marjan Kuijer ${ }^{3}$, Frits R. Rosendaal, M.D., Ph.D. ${ }^{6}$, Meta Roestenberg, M.D. Ph.D. ${ }^{1,2}$, Leo G. Visser, M.D., Ph.D. ${ }^{2}$, Anna H.E. Roukens, M.D., Ph.D. ${ }^{2}$

1. Department of Parasitology, Leiden University Medical Center, Leiden, The Netherlands

2. Department of Infectious Diseases, Leiden University Medical Center, Leiden, The Netherlands

3. Department of Immune Surveillance, National Institute for Public Health and the Environment, The Netherlands

4. Centre for Human Drug Research, Leiden, The Netherlands

5. Department of Medical Microbiology, Leiden University Medical Center, Leiden, The Netherlands

6. Department of Clinical Epidemiology, Leiden University Medical Center, Leiden, The Netherlands

\section{Corresponding author:}

Anna Roukens

Department of Infectious Diseases C5-P

Leiden University Medical Center

Albinusdreef 2, 2333 ZA Leiden, the Netherlands

Tel: +31715262613

Email: a.h.e.roukens@lumc.nl 
medRxiv preprint doi: https://doi.org/10.1101/2021.07.27.21261116; this version posted July 28,2021 . The copyright holder for this preprint

(which was not certified by peer review) is the author/funder, who has granted medRxiv a license to display the preprint in perpetuity.

All rights reserved. No reuse allowed without permission.

\section{Abstract \\ Background}

There is an urgent need for fair and equitable access to safe and effective vaccines to end the COVID-19 pandemic. Shortages in reagents and vaccines are a major challenge, as well as limited knowledge on dose response relationship with mRNA COVID-19 vaccines. We explored intradermal fractional dose administration of a mRNA SARS-CoV-2/COVID-19 vaccine as a potential dose-sparing strategy.

\section{Methods}

We conducted a proof-of-concept, dose-escalation, open-label, randomised-controlled vaccine trial (IDSCOVA) in healthy adults aged 18-30 years. To test initial safety, ten participants received $10 \mu \mathrm{g}$ mRNA-1273 vaccine through intradermal injection at day 1 and 29. Following a favourable safety review, thirty participants were 1:1 randomised to receive $20 \mu \mathrm{g}$ mRNA-1273 either intradermally or intramuscularly. The primary endpoint was tolerability and safety. The secondary endpoint was seroconversion and specific IgG concentration against SARSCoV-2 spike S1 and Receptor Binding Domain (RBD) after the second dose at day 43. We compared results to two historical cohorts of non-hospitalised COVID-19 patients and vaccinated individuals.

\section{Findings}

Thirty-eight of forty included participants (median age 25 years) completed the study. There were no serious adverse events. Self-reported local adverse reactions after intradermal delivery were mild, both in the $10 \mu \mathrm{g}$ and the $20 \mu \mathrm{g}$ group. In the higher dose group, systemic adverse reactions were more common, but still well tolerated. All 38 participants mounted substantially higher IgG-anti-S1 and IgG-anti-RBD concentrations at day 43 than COVID-19 controls. At day 43, anti-S1 (95\% CI) was 1,696 (1,309-2,198) BAU/mL for the $10 \mu \mathrm{g}$ intradermal group, 1,406 (953.5-2,074) BAU/mL for the $20 \mu \mathrm{g}$ intramuscular group and 2,057 (1,421-2,975) BAU/mL for the $20 \mu \mathrm{g}$ intradermal group. Anti-S1 was $107 \cdot 2(63-182 \cdot 2) \mathrm{BAU} / \mathrm{mL}$ for the convalescent plasma control group and $1,558(547 \cdot 8-4,433) \mathrm{BAU} / \mathrm{mL}$ for the individuals vaccinated with $100 \mu \mathrm{g}$ mRNA-1273.

\section{Interpretation}

Intradermal administration of $10 \mu \mathrm{g}$ and $20 \mu \mathrm{g}$ mRNA-1273 vaccine was well tolerated and safe, and resulted in a robust antibody response. Intradermal vaccination has the potential to be deployed for vaccine dose-sparing.

\section{Funding}

The trial was supported by crowdfunding (Wake Up to Corona). 
medRxiv preprint doi: https://doi.org/10.1101/2021.07.27.21261116; this version posted July 28, 2021. The copyright holder for this preprint (which was not certified by peer review) is the author/funder, who has granted medRxiv a license to display the preprint in perpetuity. All rights reserved. No reuse allowed without permission.

\section{Introduction}

The severe acute respiratory syndrome coronavirus-2 (SARS-CoV-2) has caused a worldwide pandemic since December 2019. The virus has now affected over 190 million people. ${ }^{1}$ SARS-CoV-2 is still spreading in many parts of the world resulting in the rise of multiple variants of concern through adaptive deletions and mutations. ${ }^{2}$ These variants are generally characterised by an increased transmissibility and decreased susceptibility to neutralising antibodies, making a fast, fair and equitable access to safe and effective COVID-19 vaccines for all countries of the world of utmost importance to protect the most vulnerable and to halt the devasting global morbidity and mortality. ${ }^{3}$

Currently, five vaccines are listed by the World Health Organization (WHO) for emergency use. ${ }^{4}$ These vaccines are limited in supply, especially in low- and middle-income countries, leading to substantial morbidity and mortality. ${ }^{5}$ A large unvaccinated population continues to pose a threat of a continuous emergence of new SARSCoV-2 variants that may be more infectious, more malignant and more resistant to vaccines than current strains. ${ }^{6}$ Despite the COVID-19 Vaccines Global Access (COVAX) Facility initiated by the WHO to provide vaccine access for low-income countries, probably $80 \%$ of the vaccine needs of participating countries will not be met soon. ${ }^{7}$ Exploring dose-sparing techniques could therefore provide the solution to immunise more people with the same vaccine stockpile.

The intramuscular injection (IM) is the standard inoculation route of vaccines. However, the papillary dermis contains a higher density of antigen presenting dendritic cells (APC) than muscle tissue, which makes it an obvious compartment to administer vaccine antigens into. ${ }^{8}$ In addition, the dermal lymphatic system is organised into several plexus systems, which aids efficient transport of vaccine antigen and APCs to the draining regional lymph nodes where further activation of B- and T-lymphocytes takes place and a protective immune response is mounted. ${ }^{9}$ As a consequence, the intradermal delivery (ID) of a fractional vaccine dose (for example $1 / 10^{\text {th }}$ or $1 / 5^{\text {th }}$ of the standard dose) introduced directly into the papillary dermis can be as effective as the IM administration of the standard dose. This has already been demonstrated for rabies, yellow fever, inactivated polio and seasonal influenza vaccine. ${ }^{10}$

Several preclinical studies support the efficacy of the intradermal route for mRNA lipid-nanoparticle (LNP)-based vaccines. In mice, it has been demonstrated that the total amount of protein produced was higher after ID delivery than IM delivery at the lowest dose of mRNA-LNP. At higher doses, saturation was reached which favoured IM delivery, showing that especially for lower mRNA doses ID delivery is the preferred route. ${ }^{11}$ In Rhesus macaques intradermal H10-mRNA-LNP influenza vaccine delivery resulted in higher antibody titers after the second dose, than IM delivery. ${ }^{12,13}$

In humans, the safety and immunogenicity of the ID administration of H10N8 mRNA-LNP influenza vaccine has been evaluated. ${ }^{14}$ The $25 \mu \mathrm{g}$ ID dose induced hemagglutination inhibition titers $>1: 40$ in $65 \%$ of participants compared with $34 \%$ of participants who received the same dose IM, confirming the high immunogenicity of the ID route at low dose. The most frequently reported adverse reactions after ID injection were: pain (82\%), erythema $(76 \%)$ and swelling (38\%) at the injection site, and fatigue (38\%), headache (26\%), myalgia (14\%), nausea (9\%) 
medRxiv preprint doi: https://doi.org/10.1101/2021.07.27.21261116; this version posted July 28, 2021. The copyright holder for this preprint (which was not certified by peer review) is the author/funder, who has granted medRxiv a license to display the preprint in perpetuity. All rights reserved. No reuse allowed without permission.

and arthralgia (3\%). No severe adverse reactions were reported. Since the ID vaccination route was associated with higher rates of solicited local reactions, the sponsor elected to discontinue the enrollment for ID administration in the study.

Given the urgent need to increase the availability of COVID-19 vaccines, we investigated the safety and tolerability of mRNA-1273 vaccine delivered intradermally. This lipid-nanoparticle (LNP)- encapsulated mRNA1273 vaccine was developed by Moderna and the Vaccine Research Center (VRC) of the National Institute of Allergy and Infectious Disease (NIAID). The mRNA vaccine is encoding for the prefusion-stabilized form of the SARS-CoV-2 spike protein (S-protein) and has a favourable thermostability. Since all mRNA vaccines are vulnerable to degradation at room temperature, they must be stored and transported frozen, via a cold supply chain. ${ }^{15}$ However, mRNA-1273 vaccine can be maintained for 30 days at 2-8 ${ }^{\circ} \mathrm{C}$, which increases feasibility of use..$^{15,16}$ The efficacy of two IM doses of $100 \mu \mathrm{g}$ mRNA-1273 vaccine was recently demonstrated to be $94 \%$ for the prevention of COVID-19 illness as compared with placebo. ${ }^{17}$

Here, we report the safety and immunogenicity of the intradermal delivery of $10 \mu \mathrm{g}$ and $20 \mu \mathrm{g}$ mRNA-1273. 
medRxiv preprint doi: https://doi.org/10.1101/2021.07.27.21261116; this version posted July 28, 2021. The copyright holder for this preprint (which was not certified by peer review) is the author/funder, who has granted medRxiv a license to display the preprint in perpetuity. All rights reserved. No reuse allowed without permission.

\section{Methods}

\section{Study design and participants}

This study was designed as a proof-of-concept, dose-escalation, open-label, randomized-controlled vaccine trial (IDSCOVA) conducted at the Leiden University Medical Center in collaboration with the Centre for Human Drug Research in the Netherlands. In the first part the tolerability, safety and immunogenicity of intradermal administration of two doses of $10 \mu \mathrm{g}$ mRNA-1273 at 28-days interval was established. Following safety review by an independent Data Safety Monitoring Board, the tolerability, safety and immunogenicity of two doses of 20 $\mu \mathrm{g}$ mRNA-1273 through ID or IM route was established in the second part.

Eligible participants were healthy adults aged 18 to 30 years. Participants were screened for SARS-CoV-2 infection by serology [SARS-CoV-2 anti-N IgG antibodies (Liaison by Diasorin, Sallugia, Italy) and SARS-CoV2 PCR of a mid-turbinate/throat swab and excluded when positive. Persons were excluded when one of the following criteria were met: having received a COVID-19 vaccine, at risk for severe COVID-19 disease, history of severe adverse or allergic reactions to previous vaccinations or any component of the study intervention, known or suspected immunodeficiency, history of autoimmune disease or active autoimmune disease requiring therapeutic intervention, use of systemic or topical corticosteroids, bleeding diathesis, pregnancy, breastfeeding or planned pregnancy within four weeks after final injection.

The trial was performed in accordance with the ethical principles of the Declaration of Helsinki and Good Clinical Practice guidelines developed by the International Harmonisation Task Force. The protocol was approved by the Medical Ethical Committee Leiden, Den Haag, Delft (NL 76702.058.21) and registered in the Netherlands Trial Register (NTR) (https://www.trialregister.nl/trial/9275). Safety was reviewed by an independent Data Safety and Monitoring Board. All participants provided written informed consent. The vaccine manufacturer was not involved in this trial.

For comparison of immunogenicity, antibody titers were compared with two previously collected cohorts of PIENTER-Corona. PIENTER-Corona is an ongoing nationwide study including all age groups of the Dutch general population, with serum samples collected at regular time intervals irrespective of the moment of infection or vaccination. For this study, convalescent sera $(n=23)$ of PCR-confirmed patients were selected that had been collected between two weeks and two months after symptom onsets from individuals aged 18-45 years with mild to moderate COVID-19 (Table S3). A second set of 20 samples were selected of vaccinated individuals without an infection history, aged 18-65 years, collected between 14 and 45 days after receiving the second IM vaccination with $100 \mu \mathrm{g}$ mRNA-1273 vaccine. The PIENTER-Corona study was approved by the medical ethical committee MED-U, Nieuwegein, the Netherlands and registered in NTR (https://www.trialregister.nl/trial/8473).

\section{Randomisation and masking}

The first part was open label. In the second part, a 1:1 randomisation was performed with sealed envelopes. Investigators and participants were not blinded; laboratory personnel was blinded for the study groups. 
medRxiv preprint doi: https://doi.org/10.1101/2021.07.27.21261116; this version posted July 28, 2021. The copyright holder for this preprint (which was not certified by peer review) is the author/funder, who has granted medRxiv a license to display the preprint in perpetuity. All rights reserved. No reuse allowed without permission.

\section{Procedures}

In part one, ten participants received $10 \mu \mathrm{g}$ mRNA through the ID route. The vaccine was prepared from the standard mRNA-1273 vaccine with a concentration of $100 \mu \mathrm{g}$ mRNA per $0 \cdot 5 \mathrm{~mL}$. We administered $0.05 \mathrm{~mL}$ ID injection in the deltoid region using a two-dose regimen with doses on day 1 and day 29. In part two, thirty participants were randomised 1:1 to receive either $20 \mu \mathrm{g}$ mRNA-1273 ID or IM with also doses on day 1 and day 29. With the standard ID injection technique, the needle was inserted at a 5-to-15 degree angle and advanced through the epidermis for approximately $3 \mathrm{~mm}$ to ensure that the entire bevel was covered by the skin. After injection a tense, pale wheal of 6 to $10 \mathrm{~mm}$ in diameter will appear over the needle bevel. The second vaccination was administered at the contralateral site to distinguish between local adverse reactions after the first and second vaccination. After each injection, the wheal size was measured, quantified in $\mathrm{mm}$ as wheal diameter across two perpendicular axes. Participants were observed for 30 minutes after vaccination to monitor acute reactions. For both part 1 and 2, the dose-escalation design specified that for each dose three sentinel participants were enrolled and monitored first. If none of the pre-specified stopping criteria were met in the first 48 hours after vaccination of the first three sentinel participants, the remaining participants were enrolled (Supplement).

\section{Monitoring of tolerability and safety}

Follow-up visits by phone were scheduled on day 2, 3, 4, 8, 15, 30, 31, 32 and 57 to assess safety outcomes. Physical follow-up visits were scheduled on day 36 and 43, i.e., seven and 14 days after the second vaccination, respectively. At each physical visit SARS-CoV-2 infection was excluded by serology and PCR. After each vaccination, participants recorded their temperature and adverse events (AEs) daily in a diary for 14 days (Supplement). Solicited AEs included nature and severity of local reactions at the injection site and regional lymph nodes, and nature and severity of systemic reactions. All local and systemic reactions were graded according to a standard grading scale (Table S1-S3). Participants were instructed not to use analgesics or antipyretics routinely before or after the vaccinations. Any use of antipyretic or pain medication that occurred in the 14 days after administration of the study intervention was registered.

\section{Safety assessments}

The primary objective of this study was to evaluate the safety, assessed by the nature, frequency and severity of solicited and unsolicited local and systemic adverse reactions and the use of antipyretics and analgesics. A secondary outcome was the diameter of the wheal in $\mathrm{mm}$ after intradermal injection, as a quality indicator of the intradermal vaccination technique.

\section{Immunogenicity}

Serum samples were collected at screening and at days 29, 36 and 43. All sera were tested for the presence of specific IgG antibodies against the nucleoprotein, Spike S1 protein and the receptor binding domain (RBD), located in the S1 subunit using a bead-based multiplex immunoassay (MIA) based on Luminex technology, as previously described. ${ }^{18,19}$ Antibody concentrations were interpolated from a 5-parameter fit of a serum pool calibrated against the WHO international reference (NIBSC, no 20/136) and reported in binding-antibody units (BAU/mL, as recently reported. ${ }^{20}$ Cutoffs for seropositivity were set to $10.08 \mathrm{BAU} / \mathrm{mL}$ for S1 and $30 \cdot 29$ for RBD with a specificity of $99.7 \%$ and $99.0 \%$ and a sensitivity of $90.9 \%$ and $91.6 \%$ for S1 and RBD respectively. 
medRxiv preprint doi: https://doi.org/10.1101/2021.07.27.21261116; this version posted July 28, 2021. The copyright holder for this preprint

(which was not certified by peer review) is the author/funder, who has granted medRxiv a license to display the preprint in perpetuity.

All rights reserved. No reuse allowed without permission.

In addition, we used MIA for detection of anti-nucleocapsid (anti-N) antibodies in parallel to assess any occurrence of SARS-CoV-2 infection following vaccination. Screening at inclusion of participants for presence of anti-N IgG was performed with the Liaison assay, as this is the in-house test available and provided a rapid result.

\section{Statistical analysis}

The sample size for this study was based on the probability of observing at least one AE for a given true event rate of a particular $\mathrm{AE}$, for a specific sample size. If the true $\mathrm{AE}$ rate is $10 \%$, then there is $65 \%$ probability of observing at least one $\mathrm{AE}$ in part one with 10 participants and 79\% in part two with 15 participants. All participants who received at least one dose of the study intervention were included for the safety analysis. Descriptive summary statistics included numbers and percentages with the indicated endpoint and the associated ClopperPearson 95\% Confidence Intervals (CI). All AEs were categorized according to the International Classification of Diseases-10 (ICD10) terms. Wheal diameter was reported as mean with standard deviation and range. Immunogenicity data were analysed using summary descriptive statistics and included all eligible randomised participants with at least one valid immunogenicity result. SARS-CoV-2-specific antibody concentrations against $\mathrm{S} 1$ and RBD were expressed as geometric mean concentrations (GMCs) and 2-sided 95\% geometric CI. Differences between groups were evaluated using the non-parametric Kruskal-Wallis test reporting adjusted pvalues. All analyses were conducted using IBM SPSS Statistics for Windows, version 25.0. Armonk, New York: IBM Corp. Graphs were made by using GraphPad Prism version 9.0.1 for Windows, GraphPad software, San Diego, California.

\section{Role of funding source}

The funders of the study had no role in the study design, data collection, data analysis, data interpretation and writing of the report. All authors had full access to all the data in the study and had final responsibility for the analyses and report.

\section{Results}

Study population

Between April $15^{\text {th }}$ and May $3^{\text {rd }}, 2021$, ten participants were included for part one, and thirty were included for part 2. After the first vaccination, one participant withdrew as she was offered a regular COVID-19 vaccination by her employer and one participant withdrew due to personal reasons (Figure 1). The characteristics of included participants are given in Table 1. 
medRxiv preprint doi: https://doi.org/10.1101/2021.07.27.21261116; this version posted July 28,2021 . The copyright holder for this preprint (which was not certified by peer review) is the author/funder, who has granted medRxiv a license to display the preprint in perpetuity. All rights reserved. No reuse allowed without permission.

\section{Figure 1. Flow-chart of inclusions}

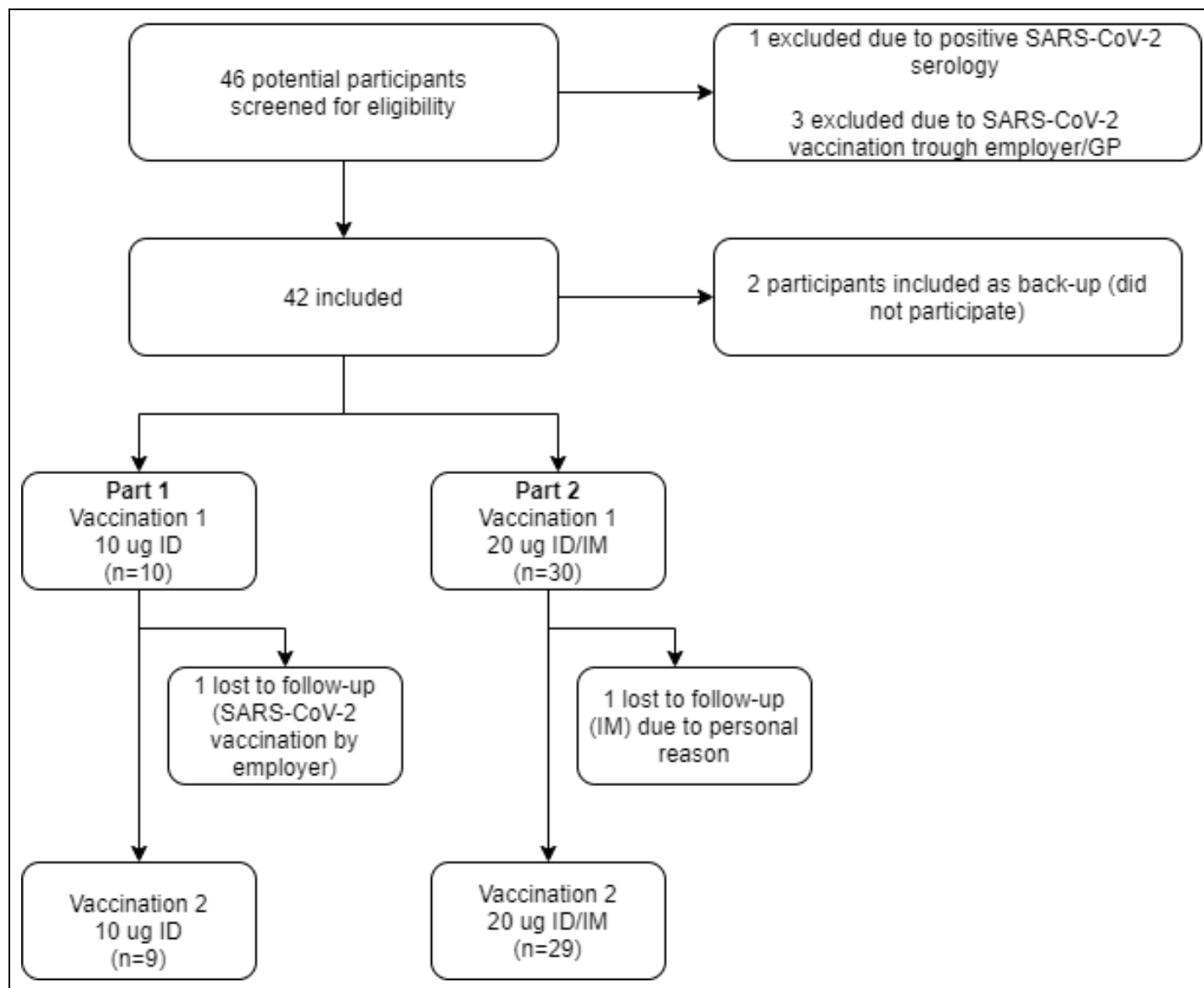

Figure 1. Flow-chart of inclusions in part 1 and 2. ID = Intradermal, IM = Intramuscular, GP = General Practitioner

\begin{tabular}{|c|c|c|c|}
\hline & $\begin{array}{c}10 \mu \mathrm{g} \text { ID } \\
(\mathrm{n}=10)\end{array}$ & $\begin{array}{c}20 \mu \mathrm{g} \text { ID } \\
(\mathrm{n}=15)\end{array}$ & $\begin{array}{c}20 \mu \mathrm{g} \text { IM } \\
(\mathrm{n}=15)\end{array}$ \\
\hline Female, n (\%) & $4(40)$ & $9(60)$ & $7(47)$ \\
\hline \multicolumn{4}{|l|}{ Age, years } \\
\hline Mean (SD) & $24(4)$ & $26(3)$ & $24(3)$ \\
\hline Range & $18-28$ & $19-29$ & $19-30$ \\
\hline \multicolumn{4}{|l|}{ BMI, $\mathrm{kg} / \mathrm{m}^{2}$} \\
\hline Mean (SD) & $24(4)$ & $26(3)$ & $24(3)$ \\
\hline Range & $20-25$ & $20-30$ & $19-30$ \\
\hline
\end{tabular}

Table 1. General characteristics of the participants at inclusion. SD = Standard Deviation. BMI = Body Mass Index. ID = Intradermal. IM = Intramuscular. 
medRxiv preprint doi: https://doi.org/10.1101/2021.07.27.21261116; this version posted July 28,2021 . The copyright holder for this preprint (which was not certified by peer review) is the author/funder, who has granted medRxiv a license to display the preprint in perpetuity. All rights reserved. No reuse allowed without permission.

\section{Safety}

There were no serious adverse events (SAE) and none of the pre-specified study stopping rules were met. An overview of vaccine-related adverse reactions is shown in Figure 2. No acute adverse reactions occurred in the first 30 minutes after vaccine administration. In total, four participant used antipyretic medication to treat vaccinerelated $\mathrm{AE}$ after the first vaccination and 4 participants used antipyretic medication after the second vaccination (Table S4). Most AEs lasted 1 or 2 days on average with no AE lasting longer than 7 days, with an exception to hyperpigmentation (Table S5), which lasted up to 44 days in one participant (Figure S1A).

Figure 2. Local and systemic adverse events related to the vaccination

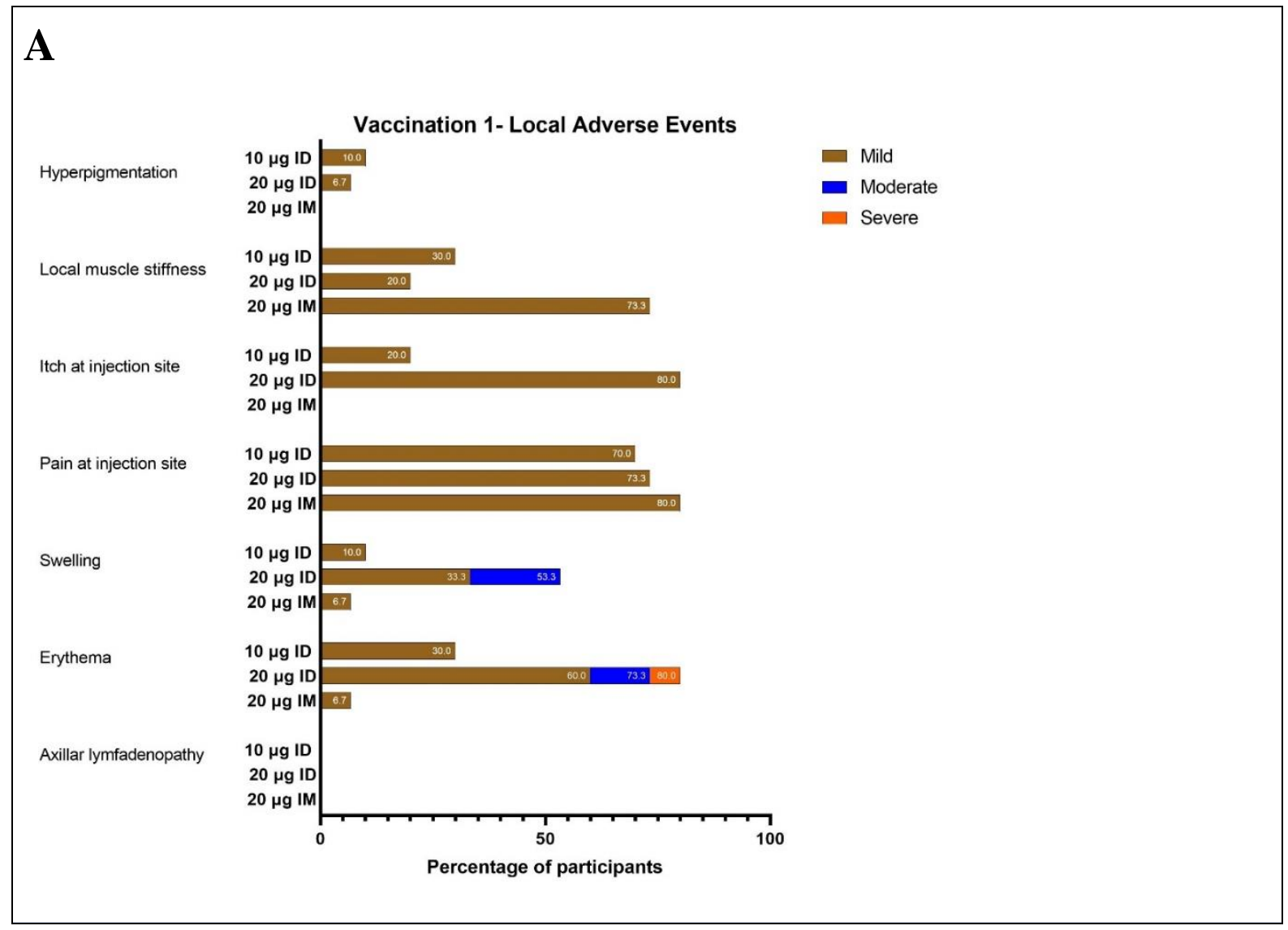


medRxiv preprint doi: https://doi.org/10.1101/2021.07.27.21261116; this version posted July 28, 2021. The copyright holder for this preprint (which was not certified by peer review) is the author/funder, who has granted medRxiv a license to display the preprint in perpetuity.

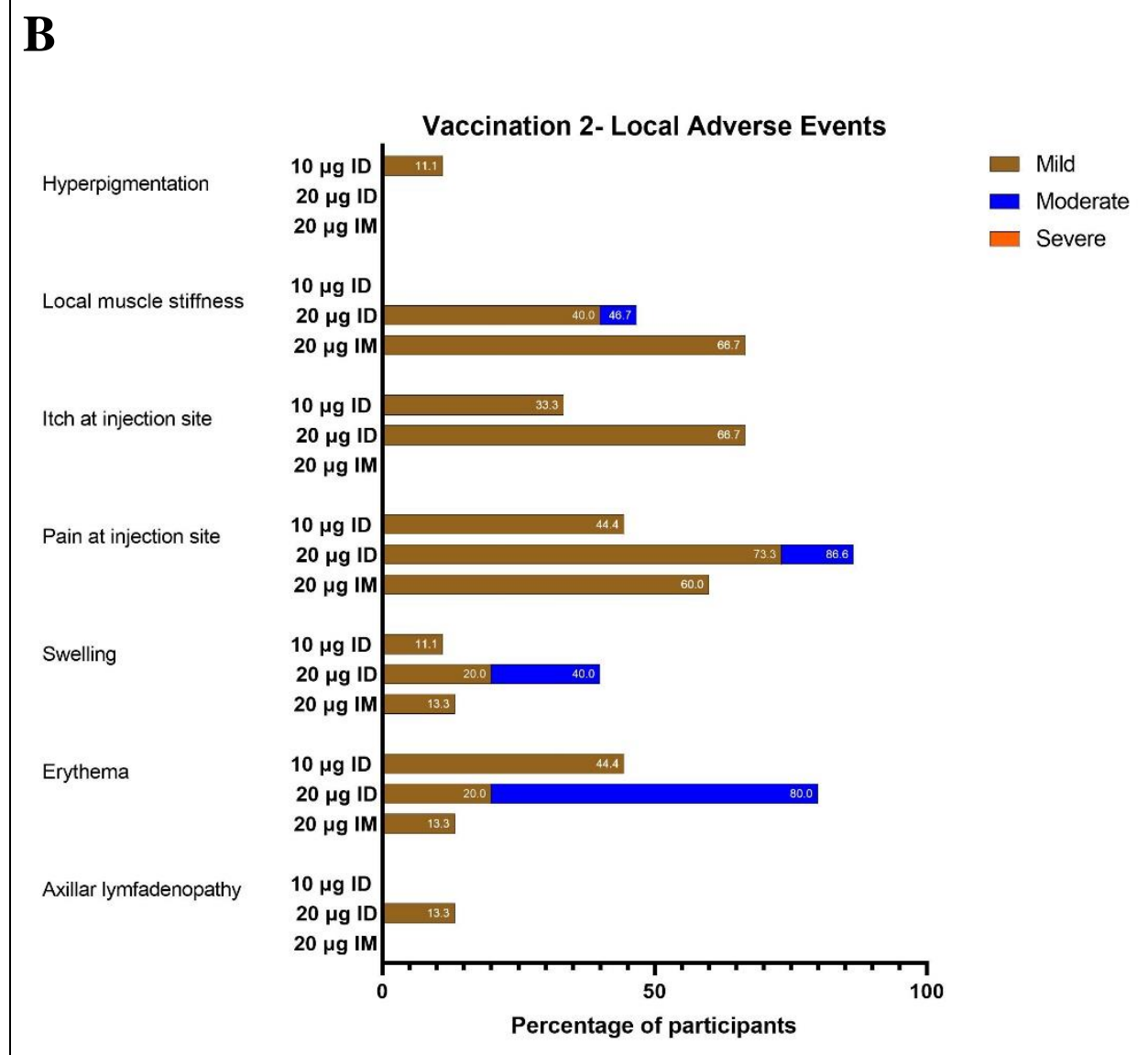

C

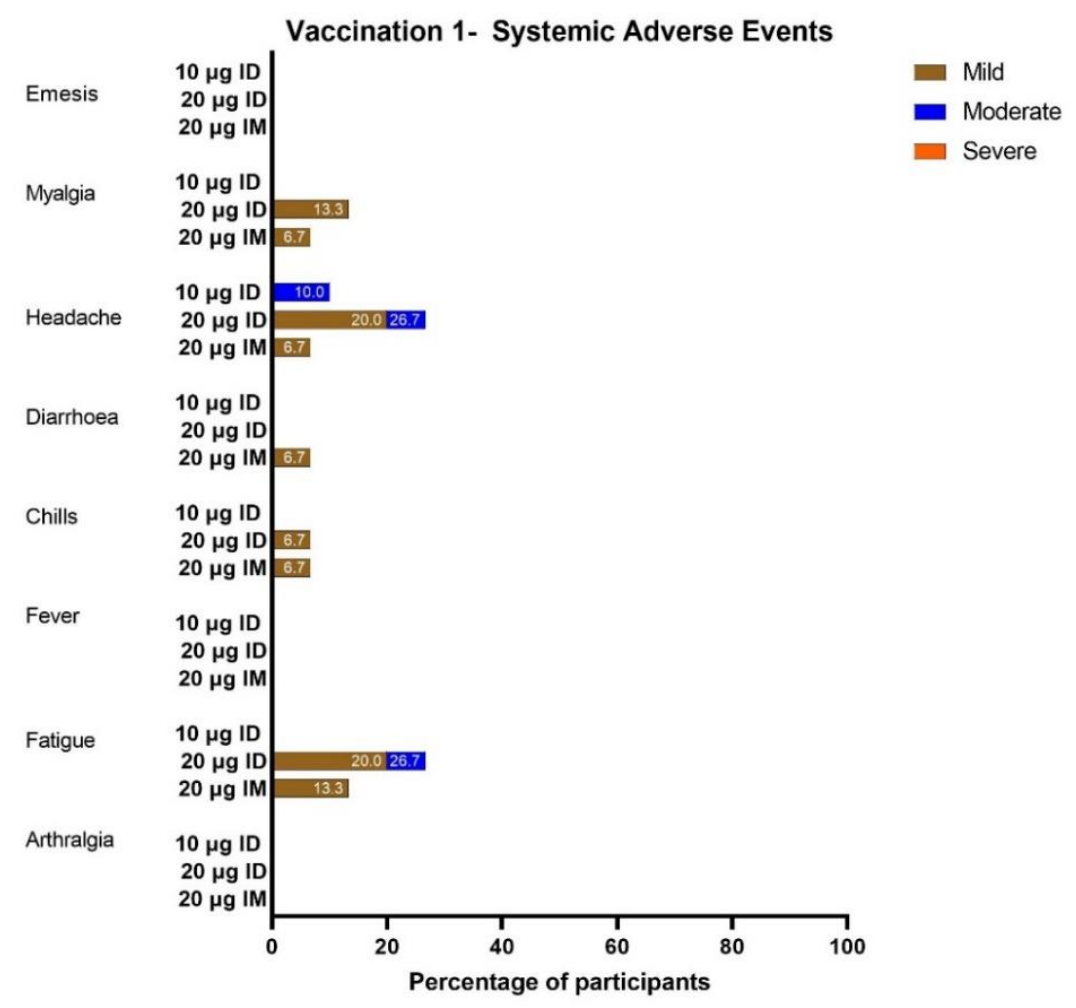




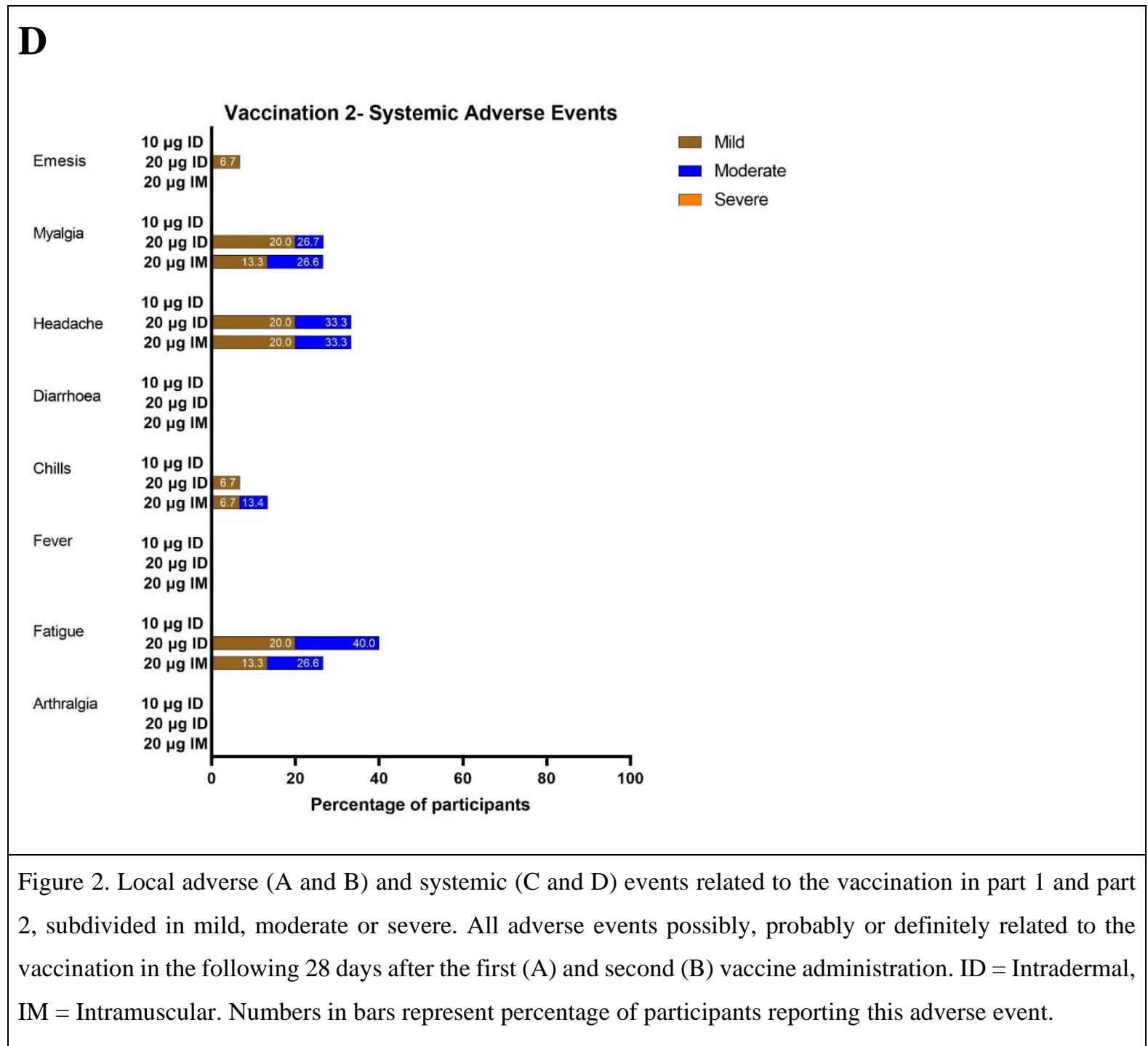

\section{Local AEs}

After the first vaccination in the $10 \mu \mathrm{g}$ ID group, the most commonly reported local adverse reaction was pain at the injection site (70\%). After the second vaccination, nine participants experienced local reactions, all reported as mild. The most prevalent AEs were erythema (44.4\%), pain (44.4\%), and itch (33\%) at the injection site.

In the $20 \mu \mathrm{g}$ groups, ID vaccination elicited more local AEs than IM vaccination.

After the first vaccination, most common local AEs in the $20 \mu \mathrm{g}$ ID group were itch (80\%) and erythema (80\%). One participant in this group reported severe erythema of more than $10 \mathrm{~cm}$ in diameter and moderate swelling. This lasted for about six days, was self-limiting and well tolerated (Figure S1C). Most common local AEs in the $20 \mu \mathrm{g}$ IM group was pain at the injection site (80\%).

In both the $20 \mu \mathrm{g}$ ID and IM group, local AEs were less common after the second vaccination. Local pain (86.6\%) and erythema (80\%) were most reported after the second $20 \mu \mathrm{g}$ ID vaccination. In the $20 \mu \mathrm{g}$ IM group, local muscle stiffness (68.7\%) and local pain (60\%) were most reported after the second vaccination. 
medRxiv preprint doi: https://doi.org/10.1101/2021.07.27.21261116; this version posted July 28, 2021. The copyright holder for this preprint

(which was not certified by peer review) is the author/funder, who has granted medRxiv a license to display the preprint in perpetuity.

All rights reserved. No reuse allowed without permission.

Information on average diameter of swelling and erythema is shown in Figure S5. The ID administrations elicited more local swelling and erythema than the IM administration, and $20 \mu \mathrm{g}$ ID more than $10 \mu \mathrm{g}$ ID. In both ID groups, there was a reoccurrence of erythema and swelling observed eight to ten days after the first vaccination. In all groups, the second vaccination caused more erythema and swelling than the first vaccination.

\section{Systemic AEs}

In the $10 \mu \mathrm{g}$ ID group, the only reported systemic AE was moderate headache in one participant (10\%) after the first vaccination.

In both the $20 \mu \mathrm{g}$ ID and IM group, the second vaccination elicited more systemic AEs than the first.

In the $20 \mu \mathrm{g}$ ID group, the most reported systemic AEs after the first and second vaccination were headache (26.7\% and $33.3 \%$, respectively) and fatigue $(26.7 \%, 40.0 \%$, respectively). In the $20 \mu \mathrm{g}$ IM group, the most reported systemic AE was fatigue (13.3\%) after the first vaccination and headache $(33.3 \%)$ after the second vaccination.

\section{Wheal diameter after intradermal vaccination}

The average wheal size after the first and second intradermal vaccination with $10 \mu \mathrm{g}(0.05 \mathrm{~mL})$ was $8 \mathrm{~mm}$ (SD 1; range $6-9 \mathrm{~mm}$ ) and $7 \mathrm{~mm}$ (SD 1; range $7-8 \mathrm{~mm})$, respectively. For intradermal vaccination with $20 \mu \mathrm{g}(0 \cdot 10$ $\mathrm{mL}$ ), average wheal size was $8 \mathrm{~mm}$ (SD 1; range 6-10 $\mathrm{mm}$ ) and $10 \mathrm{~mm}$ (SD 1; range $8-10 \mathrm{~mm}$ ), respectively for the first and second vaccination.

\section{Immunogenicity}

All participants seroconverted after the first vaccine dose (Figure S3). All participants remained antiNucleoprotein IgG negative during the study (Figure 3c), indicating that their anti-SARS-CoV-2 response was elicited by the mRNA-1273 vaccine and not through natural infection.

For part 1, anti-S1 IgG titers increased rapidly after the first and second vaccination in all participants and amounted to 1,696 [95\% CI 1,309-2,198] BAU/mL on day 43 (Table 2). Similar results were found for antibodies to the RBD: anti-RBD IgG titers were 1,286 [95\% CI 1,004-1,648] BAU/mL on day 43 (Table 3).

For part 2, anti-S1 IgG titers were 2,057 BAU/mL [95\% CI 1,421-2,975] on day 43 in the ID group, and 1,406 BAU/mL [95\% CI 953-3-2,074] in the IM group (Table 2). Similar results were found for the antibodies to the RBD (Table 3)

Concentrations of S1 and RBD-specific IgG were 14 to 20 -fold higher in ID-vaccinated individuals than in convalescent sera from symptomatic, non-hospitalised patients. In these patients Anti-S1 and anti-RBD IgG titers at day 49 were $107 \cdot 2$ [95\% CI 63-182.2] and 110.9 [95\% CI 65.8-187.1], respectively (Figure 3a and 3b). IgG concentrations after 10 or $20 \mu \mathrm{g}$ ID and $20 \mu \mathrm{g}$ IM were similar to those observed in individuals of the general population after receiving $100 \mu \mathrm{g}$ IM (Figure 3a and 3b). In the latter group anti-S1 and anti-RBD titers in these patients at day 49 were 1,558;95\% CI 547-8-4433] and 1286 [95\% CI 516-3205], respectively. 
medRxiv preprint doi: https://doi.org/10.1101/2021.07.27.21261116; this version posted July 28,2021 . The copyright holder for this preprint (which was not certified by peer review) is the author/funder, who has granted medRxiv a license to display the preprint in perpetuity. All rights reserved. No reuse allowed without permission.

Table 2. IgG antibodies against Spike S1 protein of SARS CoV-2

\begin{tabular}{|l|c|c|c|}
\hline & $\begin{array}{c}\text { Part 1 } \\
\mathbf{1 0} \boldsymbol{\mu g} \text { ID } \\
(\mathbf{n = 9})\end{array}$ & $\begin{array}{c}\text { Part 2 } \\
\mathbf{2 0} \mathbf{\mu g} \text { ID } \\
(\mathbf{n = 1 5})\end{array}$ & $\begin{array}{c}\text { Part 2 } \\
\mathbf{2 0} \boldsymbol{\mu g} \text { IM } \\
(\mathbf{n = 1 4})\end{array}$ \\
\hline $\begin{array}{l}\text { Day 1 } \\
\text { (Vaccination 1) }\end{array}$ & $\begin{array}{c}0 \cdot 8 \\
(0 \cdot 430-1 \cdot 49)\end{array}$ & $\begin{array}{c}0 \cdot 32 \\
(0 \cdot 14-0 \cdot 68)\end{array}$ & $\begin{array}{c}0 \cdot 25 \\
(0 \cdot 162-0 \cdot 415)\end{array}$ \\
\hline $\begin{array}{l}\text { Day 29 } \\
\text { (Vaccination 2) }\end{array}$ & $\begin{array}{c}337 \cdot 1 \\
(237 \cdot 1-479 \cdot 2)\end{array}$ & $\begin{array}{c}405 \cdot 6 \\
(263 \cdot 7-623 \cdot 8)\end{array}$ \\
\hline Day 36 & $\begin{array}{c}813 \cdot 8 \\
(590 \cdot 3-1,171 \cdot 9)\end{array}$ & $\begin{array}{c}972 \cdot 8 \\
(672 \cdot 8-1,409)\end{array}$ & $\begin{array}{c}612 \cdot 0 \\
(342 \cdot 7-1,093)\end{array}$ \\
\hline Day 43 & $\begin{array}{c}1,696 \\
(1,308 \cdot 9-2,197 \cdot 9)\end{array}$ & $\begin{array}{c}2,057 \\
(1,421-2,975)\end{array}$ \\
\hline
\end{tabular}

Geometric mean concentrations of anti-S1 antibodies (95\% CI) in BAU/mL. BAU = Binding Antibody Units, $\mathrm{CI}=$ Confidence Intervals. Cut off for seropositivity is $10.08 \mathrm{BAU} / \mathrm{mL}$.

Table 3. IgG antibodies against RBD of SARS CoV-2

\begin{tabular}{|c|c|c|c|}
\hline & $\begin{array}{c}\text { Part } 1 \\
10 \mu g \text { ID } \\
(n=9)\end{array}$ & $\begin{array}{c}\text { Part } 2 \\
20 \mu g \text { ID } \\
(n=15)\end{array}$ & $\begin{array}{c}\text { Part } 2 \\
20 \mu \mathrm{g} I M \\
(\mathrm{n}=14)\end{array}$ \\
\hline $\begin{array}{l}\text { Day } 1 \\
\text { (Vaccination } 1 \text { ) }\end{array}$ & $1 \cdot 6(0 \cdot 9-3 \cdot 3)$ & $1(0 \cdot 6-1 \cdot 8)$ & $0 \cdot 8(0 \cdot 6-1 \cdot 1)$ \\
\hline $\begin{array}{l}\text { Day } 29 \\
\text { (Vaccination 2) }\end{array}$ & $201 \cdot 8(141 \cdot 8-287 \cdot 3)$ & $257(166 \cdot 8-396)$ & $134 \cdot 3(80 \cdot 9-222 \cdot 8)$ \\
\hline Day 36 & $580(413 \cdot 9-812 \cdot 6)$ & $631 \cdot 9(444 \cdot 7-898 \cdot 1)$ & $367 \cdot 4(203 \cdot 6-663 \cdot 2)$ \\
\hline Day 43 & $1,286(1,003-1,648)$ & $1,471(1,013-2,137)$ & $993 \cdot 5(659 \cdot 5-1,497)$ \\
\hline
\end{tabular}

Geometric mean concentrations of anti-RBD antibodies (95\% CI) in BAU/mL. BAU = Binding Antibody Units, $\mathrm{CI}=$ Confidence Intervals. Cut off for seropositivity is $10.08 \mathrm{BAU} / \mathrm{mL}$. 
medRxiv preprint doi: https://doi.org/10.1101/2021.07.27.21261116; this version posted July 28,2021 . The copyright holder for this preprint (which was not certified by peer review) is the author/funder, who has granted medRxiv a license to display the preprint in perpetuity. All rights reserved. No reuse allowed without permission.

Figure 3. Anti-SARS-CoV-2 antibody concentrations

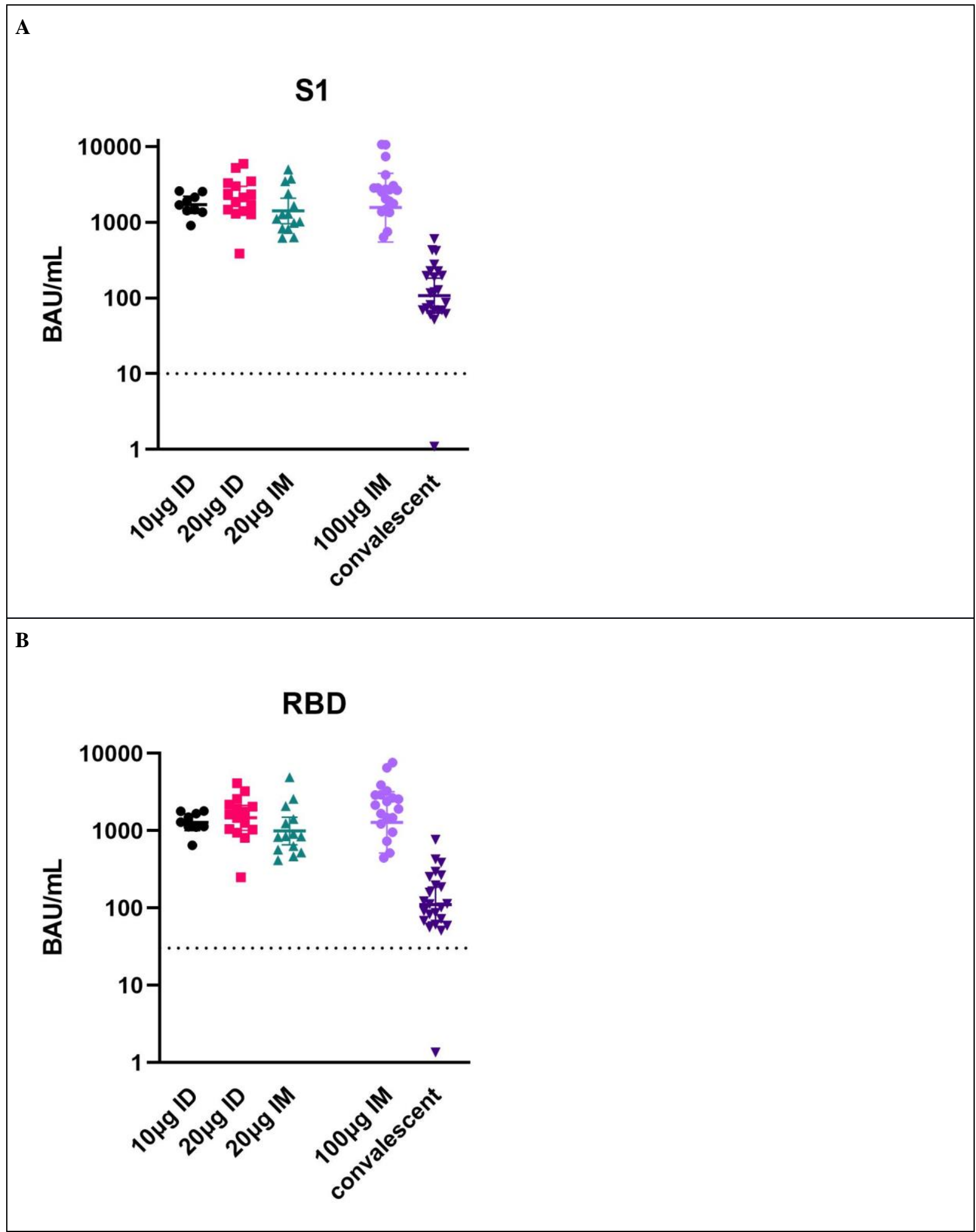




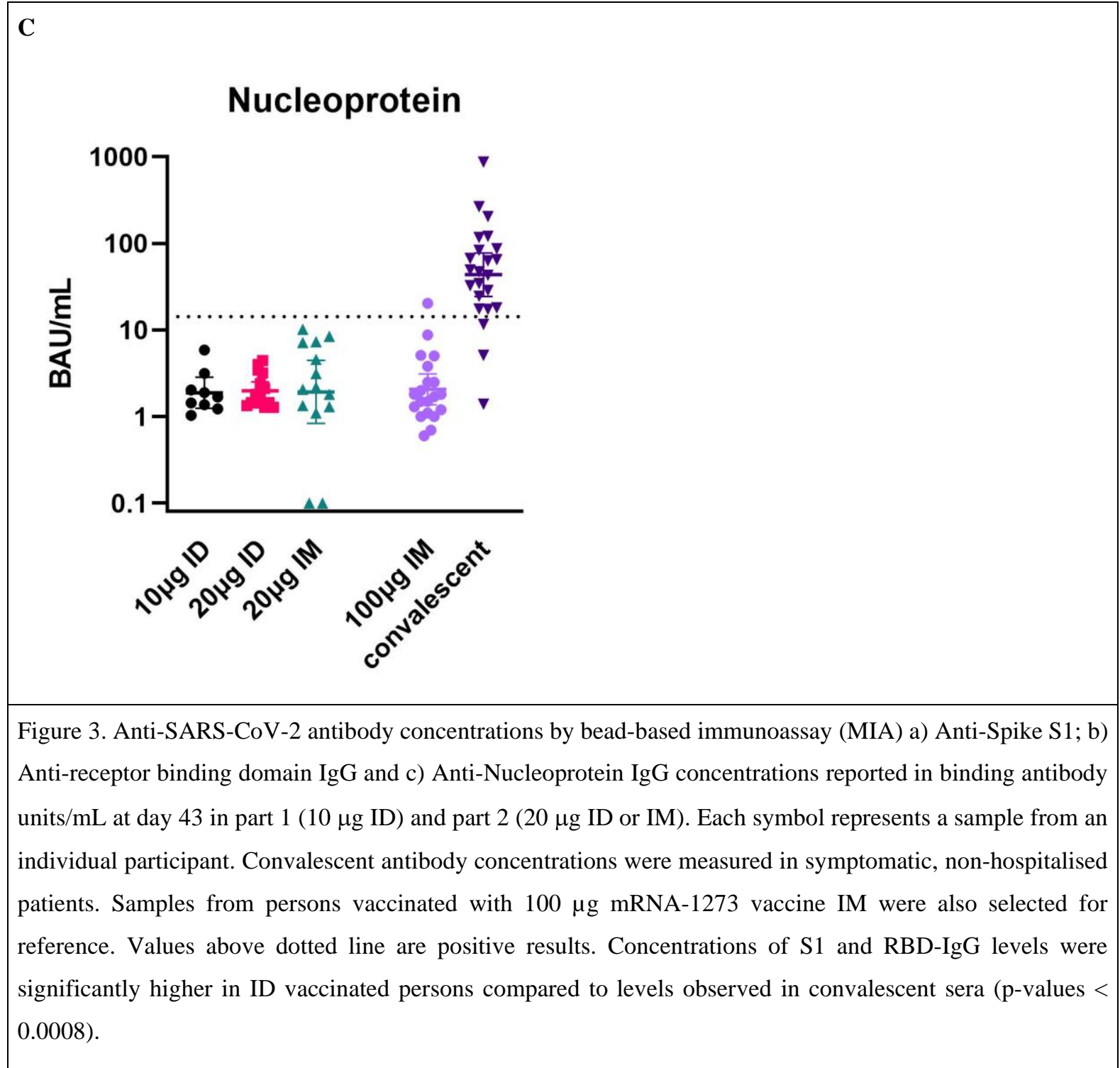


medRxiv preprint doi: https://doi.org/10.1101/2021.07.27.21261116; this version posted July 28, 2021. The copyright holder for this preprint (which was not certified by peer review) is the author/funder, who has granted medRxiv a license to display the preprint in perpetuity. All rights reserved. No reuse allowed without permission.

\section{Discussion}

We report results of a proof of concept, open-label, dose-escalation vaccine trial, and show that intradermal delivery of a two-dose regimen of $10 \mu \mathrm{g}$ or $20 \mu \mathrm{g}$ fractional dose of mRNA-1273 SARS-CoV-2 vaccine in healthy adults was safe, well tolerated and immunogenic. These findings support further exploration of the intradermal delivery of a fractional dose of mRNA-1273 vaccine as a dose-sparing strategy. Fractional dose intradermal vaccination has previously been investigated as a dose-sparing strategy for several vaccines (e.g. influenza, rabies, hepatitis A and B, measles, DTP), ${ }^{9}$ but not for a registered COVID-19 vaccine.

The most commonly reported adverse reactions were short-lasting and consisted of mild pain, itching, erythema and swelling at the injection site. These local reactions are similar to those reported after intradermal vaccination with other vaccines. ${ }^{10}$ Delayed injection-site reactions, with an onset of ten days or more after injection, were uncommon.

In this study, we showed that a two-dose regimen of $10 \mu \mathrm{g}$ or $20 \mu \mathrm{g}$ mRNA SARS-CoV-2 vaccine, administered intradermally, induced a homogeneous rapid and robust increase in anti-S1 and anti-RBD antibodies by day 43 in all participants. These titers were considerably higher (14 to 20-fold) than antibody concentrations in convalescent samples. Post-vaccination titers were in the same range as samples from individuals vaccinated with two doses of $100 \mu \mathrm{g}$ mRNA-1273, suggesting that a dose-sparing strategy using $1 / 10^{\text {th }}$ or $1 / 5^{\text {th }}$ dose of mRNA-vaccine provided sufficient protective immunity. The reduced dosage did not result in any primary vaccine failure among the twenty-four volunteers who received the vaccine at reduced dosage.

The relationship between specific IgG concentrations and the capacity to neutralise SARS-CoV-2 is currently under investigation. A first indication of the degree of neutralising capacity of antibodies induced by ID administration as presented in this study can be derived from a recent study showing the relationship between vaccine efficacy and virus neutralisation titers. ${ }^{21}$ Sera from mRNA-1273 vaccinated individuals had roughly four times better neutralization activity than convalescent sera. Also in this study, ID and IM administration of mRNA1273 resulted in considerably higher concentrations of antibodies than convalescent serum. Since ID vaccination induced antibody levels similar to IM administration, the antibody levels reported here likely have high neutralising capacity.

This study has some limitations. Although the concentrations of anti-S1 IgG were higher at each time point, the limited sample size did not allow to demonstrate superiority of intradermal delivery over intramuscular injection. In addition, since we included healthy volunteers aged 18-30 years old, the results on safety and immunogenicity may not apply to the general population. Finally, the longevity of the immune response past day 43 was not assessed, as some participants opted for receiving the regular vaccine through the national COVID-19 vaccination program at day 57.

Although the relative importance of neutralization antibodies with regard to protection from COVID-19 has not yet been fully characterized, high levels of neutralising antibodies have been shown in early preclinical Rhesus macaque studies ${ }^{22}$, in convalescent individuals ${ }^{23,24}$ and in recently reported vaccine trials. ${ }^{25,26}$ Additional 
medRxiv preprint doi: https://doi.org/10.1101/2021.07.27.21261116; this version posted July 28, 2021. The copyright holder for this preprint (which was not certified by peer review) is the author/funder, who has granted medRxiv a license to display the preprint in perpetuity. All rights reserved. No reuse allowed without permission.

measurements of neutralising antibodies and T-cell responses will be performed at a later part and will provide more information on the robustness and longevity of the immune response.

In conclusion, we show that the ID administration of $10 \mu \mathrm{g}$ and $20 \mu \mathrm{g}$ mRNA-1273 vaccine resulted in a robust, homogeneous, immune response with an acceptable safety profile in healthy adults aged 18-30 years. These safety and immunogenicity results support advancement of the investigation of the intradermal route for administration of the fractional doses of the mRNA-1273 vaccine to later-stage clinical trials. A randomised non-inferiority trial of $20 \mu \mathrm{g}$ mRNA-1273 administered ID vs $100 \mu \mathrm{g}$ mRNA-1273 administered IM is in preparation (part 3). When part 3 of this trial confirms these preliminary findings, ID administration will bear great potential as a dose-sparing strategy in countries where vaccination campaigns are still at an early stage and could be a true turning point in this pandemic that has gripped the world for one and a half years. 
medRxiv preprint doi: https://doi.org/10.1101/2021.07.27.21261116; this version posted July 28,2021 . The copyright holder for this preprint

(which was not certified by peer review) is the author/funder, who has granted medRxiv a license to display the preprint in perpetuity.

All rights reserved. No reuse allowed without permission.

\section{References}

1. WHO Coronovirus (COVID-19) Dashboard. https://covid19.who.int/ (accessed July 10 2021).

2. CDC. SARS-CoV-2 Variant Classifications and Definitions. June 23th, 2021.

https://www.cdc.gov/coronavirus/2019-ncov/variants/variant-info.html (accessed June 232021 ).

3. Prompetchara E, Ketloy C, Palaga T. Immune responses in COVID-19 and potential vaccines: Lessons learned from SARS and MERS epidemic. Asian Pac J Allergy Immunol 2020; 38(1): 1-9.

4. WHO. WHO lists additional COVID-19 vaccine for emergency use and issues interim policy recommendations. May 7th, 2021. . https://www.who.int/news/item/07-05-2021-who-lists-additional-covid-19vaccine-for-emergency-use-and-issues-interim-policy-recommendations (accessed June 23 2021).

5. Acharya KP, Ghimire TR, Subramanya SH. Access to and equitable distribution of COVID-19 vaccine in low-income countries. NPJ Vaccines 2021; 6(1): 54.

6. Sah P, Vilches TN, Moghadas SM, et al. Accelerated vaccine rollout is imperative to mitigate highly transmissible COVID-19 variants. EClinicalMedicine 2021; 35: 100865.

7. Figueroa JP BM, Hotez P, et al. Urgent needs of low-income and middle-income countries for COVID19 vaccines and therapeutics. Lancet 2021; 397(10274): 562-4.

8. Nicolas JF, Guy B. Intradermal, epidermal and transcutaneous vaccination: from immunology to clinical practice. Expert Rev Vaccines 2008; 7(8): 1201-14.

9. Huggenberger R, Detmar M. The cutaneous vascular system in chronic skin inflammation. J Investig Dermatol Symp Proc 2011; 15(1): 24-32.

10. Intradermal Delivery of Vaccines. A review of the literature and the potential for development for use in low- and middle-income countries 2009

https://www.who.int/immunization/programmes_systems/supply_chain/optimize/Intradermal-deliveryvaccines_report_2009-Sept.pdf (accessed July 1 2021).

11. Pardi N, Tuyishime S, Muramatsu H, et al. Expression kinetics of nucleoside-modified mRNA delivered in lipid nanoparticles to mice by various routes. J Control Release 2015; 217: 345-51.

12. Liang F, Lindgren G, Lin A, et al. Efficient Targeting and Activation of Antigen-Presenting Cells In Vivo after Modified mRNA Vaccine Administration in Rhesus Macaques. Mol Ther 2017; 25(12): 2635-47. 13. Lindgren G, Ols S, Liang F, et al. Induction of Robust B Cell Responses after Influenza mRNA Vaccination Is Accompanied by Circulating Hemagglutinin-Specific ICOS+ PD-1+ CXCR3+ T Follicular Helper Cells. Front Immunol 2017; 8: 1539.

14. Feldman RA, Fuhr R, Smolenov I, et al. mRNA vaccines against H10N8 and H7N9 influenza viruses of pandemic potential are immunogenic and well tolerated in healthy adults in phase 1 randomized clinical trials. Vaccine 2019; 37(25): 3326-34.

15. Moderna. Fact Sheet for Healthcare Providers Administering Vaccine. 2021.

https://www.fda.gov/media/144637/download (accessed July 12021 ).

16. Kaiser J. Temperature concerns could slow the rollout of new coronavirus vaccines. 2020.

https://www.sciencemag.org/news/2020/11/temperature-concerns-could-slow-rollout-new-coronavirus-vaccines (accessed July 12021 ).

17. Baden LR, El Sahly HM, Essink B, et al. Efficacy and Safety of the mRNA-1273 SARS-CoV-2 Vaccine. N Engl J Med 2021; 384(5): 403-16.

18. den Hartog G, Schepp RM, Kuijer M, et al. SARS-CoV-2-Specific Antibody Detection for Seroepidemiology: A Multiplex Analysis Approach Accounting for Accurate Seroprevalence. J Infect Dis 2020; 222(9): 1452-61.

19. den Hartog G, Vos ERA, van den Hoogen LL, et al. Persistence of antibodies to SARS-CoV-2 in relation to symptoms in a nationwide prospective study. Clin Infect Dis 2021.

20. Geers D, Shamier MC, Bogers S, et al. SARS-CoV-2 variants of concern partially escape humoral but not T-cell responses in COVID-19 convalescent donors and vaccinees. Sci Immunol 2021; 6(59).

21. Khoury DS, Cromer D, Reynaldi A, et al. Neutralizing antibody levels are highly predictive of immune protection from symptomatic SARS-CoV-2 infection. Nat Med 2021; 27(7): 1205-11.

22. $\mathrm{Yu}$ J, Tostanoski LH, Peter L, et al. DNA vaccine protection against SARS-CoV-2 in rhesus macaques. Science 2020; 369(6505): 806-11.

23. Robbiani DF, Gaebler C, Muecksch F, et al. Convergent antibody responses to SARS-CoV-2 in convalescent individuals. Nature 2020; 584(7821): 437-42.

24. Wang X, Guo X, Xin Q, et al. Neutralizing Antibody Responses to Severe Acute Respiratory Syndrome Coronavirus 2 in Coronavirus Disease 2019 Inpatients and Convalescent Patients. Clin Infect Dis 2020; 71(10): 2688-94.

25. Okba NMA, Müller MA, Li W, et al. Severe Acute Respiratory Syndrome Coronavirus 2-Specific Antibody Responses in Coronavirus Disease Patients. Emerg Infect Dis 2020; 26(7): 1478-88.

26. Jackson NAC, Kester KE, Casimiro D, Gurunathan S, DeRosa F. The promise of mRNA vaccines: a biotech and industrial perspective. NPJ Vaccines 2020; 5(1): 11. 